\title{
GENDER DAN PERILAKU MEMILIH: SEBUAH KAJIAN PSIKOLOGI POLITIK
}

\author{
Rahmaturrizqi, Choirun Nisa, dan Fathul Lubabin Nuqul \\ Fakultas Psikologi Universitas Islam Negeri Maulana Malik Ibrahim Malang \\ e-mail: fathullubabinnuqul@yahoo.co.id
}

\begin{abstract}
Gender and Voting Behavior: A Political Psychological study. There are interesting developments of political psychology, particularly in the effort of women in politics arena. Until the mid-year 2007, at least 82 women were recorded following the elections in 232 provincial-level regions and districts level. Out of the above, 26 women (30.76\%) registered as a candidate for the leader of region and 57 women (69.24\%), registered as a deputy leader of the region, although only eight women who are successfully elected as the leader of region and 11 elected as deputy leaders of regional (Arifin, 2008). With direct elections as happened today, making the candidates should follow the "interest" of voters. Efforts to understand the voter's behavior, feelings and thinking do not always easy. The old ways by making a donation of material deemed not affect voters more powerful. One possible solution is the assessment needs of the voter. To fulfill voter's needs is not always easy because there are differences of character between communities, genders and individuals that influence their voting behavior. The study involved 90 students (45 women and 45 men). Data were collected from participants' responses to scenarios about election for leader of region (bupati). All participants chose male or female candidates as a leader, or not vote at all. Each participants was asked to give a reason for their alternative answer to the scenarios. Data were analysed using qualitative thematic analysis and cross tabulation. The results showed that the number of subjects who choose a man as a leader was 68 people or $75.56 \%$, and only 12 subjects or $13.33 \%$ who chose women as a leader. Subjects who abstained were 11 people or $11.11 \%$. The results showed that women's voting behavior, are more likely to choose a man as a leader. From various reasons posed by participants, this study concluded that the tendency was caused by the participants' beliefs, including women's beliefs, that men are more entitled and deserved to be a leader than women
\end{abstract}

Keywords: Voting behavior, gender, political psychology

\begin{abstract}
Abstrak: Ada perkembangan menarik dari psikologi politik, terutama dalam upaya perempuan untuk bersaing dalam arena politik. Sampai pertengahan tahun 2007, sedikitnya 82 perempuan tercatat mengikuti pemilihan di 232 daerah tingkat provinsi dan tingkat kabupaten. Dari data tersebut, 26 perempuan $(30,76 \%)$ terdaftar sebagai calon pemimpin daerah dan 57 wanita $(69.24 \%)$, terdaftar sebagai wakil pemimpin daerah, meskipun hanya delapan perempuan yang berhasil terpilih sebagai pemimpin daerah dan 11 terpilih sebagai wakil pemimpin daerah (Arifin, 2008). Pemilihan langsung seperti yang terjadi saat ini membuat calon harus mengikuti "kepentingan" pemilih. Namun, upaya untuk memahami perilaku, perasaan dan pemikiran pemilih tidak selalu mudah. Cara-cara lama dengan memberikan sumbangan ekonomi dianggap tidak terlalu kuat lagi dalam mempengaruhi suara pemilih. Salah satu solusi yang mungkin adalah melakukan analisis kebutuhan pemilih. Untuk memenuhi kebutuhan pemilih tidak selalu mudah karena ada perbedaan karakter antara masyarakat, jenis kelamin dan individu yang mempengaruhi perilaku memilih mereka. Penelitian ini melibatkan 90 mahasiswa (45 perempuan dan 45 laki-laki). Data dikumpulkan dengan cara memberikan cerita skenario tentang pemilihan pemimpin daerah (bupati) di mana setiap subjek harus memilih pria atau wanita sebagai pemimpin, atau tidak memilih sama sekali. Setiap alternatif jawaban, subjek diminta untuk memberikan alasan. Analisis data menggunakan tematik dan tabulasi silang kualitatif. Hasil penelitian menunjukkan bahwa subjek yang memilih pria sebagai pemimpin sebanyak 68 orang atau 75,56\%, dan yang memilih perempuan sebagai pemimpin hanya 12 orang atau 13,33\%. Subjek yang abstain berjumlah 11 orang atau $11,11 \%$. Hasil ini menunjukkan bahwa perilaku pemilih perempuan, lebih cenderung memilih pria sebagai pemimpin. Dari berbagai alasan yang diungkapkan oleh subjek dapat disimpulkan bahwa hal ini terjadi karena sebagian besar subjek, termasuk perempuan, percaya
\end{abstract}


bahwa pria lebih berhak dan pantas untuk menjadi pemimpin dibanding perempuan.

Kata kunci : Perilaku memilih, gender, psikologi politik

Saat ini di beberapa daerah telah diramaikan dengan acara pemilihan kepala daerah. Dari beberapa daerah yang menyelenggarakan, muncul femonama yang menarik yaitu partisipasi perempuan untuk menjadi kandidat kepala daerah (Gubernur dan Wakil Gubernur atau Bupati dan Wakil Bupati). Proses pemilihan kepala daerah melalui pemilihan langsung yang berlaku seperti saat ini membuat para kandidat harus pintar mencari tahu "selera" pemilih (voter). Usaha untuk memahami perilaku, perasaan, dan pikiran pemilih tidak selamanya mudah. Cara-cara lama seperti program pemberian sumbangan dalam bentuk materi dirasa tidak ampuh lagi untuk memengaruhi pemilih. Salah satu cara yang dirasa bisa menarik pemilih adalah asesmen kebutuhan pada voter, keseimbangan gender yang diharapkan mampu menyuarakan kebutuhan voter.

Judith Squires (1999) menyatakan bahwa perempuan telah lama dan secara luas mengalami ketertinggalan dari berbagai aktivitas politik dan dihambat untuk mendefinisikan aktivitas mereka sebagai sesuatu yang menjadi bagian tidak terpisahkan dari politik. Dunia politik yang dianggap sebagai "dunia laki-laki" membuat perempuan masih enggan memasuki dunia politik karena merasa dunia politik bukan "dunia perempuan". Hal itu tidak lepas dari anggapan yang sudah ada di tengah-tengah masyarakat bahwa perempuan itu inferior, tidak pantas, atau tidak memiliki keahlian yang dibutuhkan untuk berkecimpung dalam dunia politik.

Wacana tentang keterlibatan perempuan dalam politik masih menjadi perdebatan tersendiri di kalangan masyarakat. Namun, jika dilihat dari perkembangannya sendiri, kehadiran perempuan dalam dunia politik bisa dijadikan sebuah indikasi bahwa di negara tersebut telah terjadi kemajuan demokrasi. Tuntutan adanya kesetaraan gender dalam bidang politik yang disuarakan oleh gerakan feminis di Indonesia pada akhirnya membuahkan hasil. Pemerintah akhirnya mengeluarkan kebijakan affirmatif action, yaitu memberi kuota $30 \%$ bagi perempuan dalam persaingan politik di Indonesia yang termaktub dalam Undang-Undang Pemilu No. 12 Pasal 65 Tahun 2003.

Terbukanya kesempatan bagi perempuan untuk ikut aktif secara langsung dalam dunia politik akhirnya memunculkan calon-calon pemimpin perempuan dalam pemilu, khususnya di arena Pemilihan Kepala Daerah (Pilkada). Menariknya, sampai Saat ini di beberapa daerah telah diramaikan dengan acara pemilihan kepala daerah. Dari beberapa daerah yang menyelenggarakan, muncul femonama yang menarik yaitu partisipasi perempuan untuk menjadi kandidat kepala daerah (Gubernur dan Wakil Gubernur atau Bupati dan Wakil Bupati). Proses pemilihan kepala daerah melalui pemilihan langsung yang berlaku seperti saat ini membuat para kandidat harus pintar mencari tahu "selera" pemilih (voter). Usaha untuk memahami perilaku, perasaan, dan pikiran pemilih tidak selamanya mudah. Caracara lama seperti program pemberian sumbangan dalam bentuk materi dirasa tidak ampuh lagi untuk memengaruhi pemilih. Salah satu cara yang dirasa bisa menarik pemilih adalah asesmen kebutuhan pada voter, keseimbangan gender yang diharapkan mampu menyuarakan kebutuhan voter.

Judith Squires (1999) menyatakan bahwa perempuan telah lama dan secara luas mengalami ketertinggalan dari berbagai aktivitas politik dan dihambat untuk 
mendefinisikan aktivitas mereka sebagai sesuatu yang menjadi bagian tidak terpisahkan dari politik. Dunia politik yang dianggap sebagai "dunia laki-laki" membuat perempuan masih enggan memasuki dunia politik karena merasa dunia politik bukan "dunia perempuan". Hal itu tidak lepas dari anggapan yang sudah ada di tengah-tengah masyarakat bahwa perempuan itu inferior, tidak pantas, atau tidak memiliki keahlian yang dibutuhkan untuk berkecimpung dalam dunia politik.

Wacana tentang keterlibatan perempuan dalam politik masih menjadi perdebatan tersendiri di kalangan masyarakat. Namun, jika dilihat dari perkembangannya sendiri, kehadiran perempuan dalam dunia politik bisa dijadikan sebuah indikasi bahwa di negara tersebut telah terjadi kemajuan demokrasi. Tuntutan adanya kesetaraan gender dalam bidang politik yang disuarakan oleh gerakan feminis di Indonesia pada akhirnya membuahkan hasil. Pemerintah akhirnya mengeluarkan kebijakan affirmatif action, yaitu memberi kuota $30 \%$ bagi perempuan dalam persaingan politik di Indonesia yang termaktub dalam Undang-Undang Pemilu No. 12 Pasal 65 Tahun 2003.

Terbukanya kesempatan bagi perempuan untuk ikut aktif secara langsung dalam dunia politik akhirnya memunculkan calon-calon pemimpin perempuan dalam pemilu, khususnya di arena Pemilihan Kepala Daerah (Pilkada). Menariknya, sampai dengan pertengahan tahun 2007 tercatat sekurang-kurangnya ada sekitar 82 perempuan yang ikut dalam Pilkada di 232 daerah setingkat provinsi dan kabupaten/kota. Dari jumlah itu, 26 perempuan (30,76 persen) terdaftar sebagai calon kepala daerah dan 57 perempuan sisanya $(69,24$ persen) terdaftar sebagai wakil kepala daerah, meskipun pada akhirnya hanya 8 perempuan yang berhasil terpilih sebagai kepala daerah serta 11 lainnya terpilih sebagai wakil kepala daerah (Arifin,
2008).

"Kekalahan" perempuan dalam Pilkada yang telah diselenggarakan itu pada akhirnya, secara garis besar, memunculkan dua pertanyaan penting. Pertama, apakah potensi perempuan sebagai pemimpin masih dianggap kurang? Kedua, dengan kekalahan itu apakah akan semakin menguatkan dominasi nilai peran sosial yang masih cenderung patriarki? Berdasarkan pada dua pertanyaan itu, perlu dilakukan sebuah kajian yang mendalam tentang fenomena tersebut, terutama dari sisi psikologi pemilih dalam perilaku memilik mereka.

Secara teoritis, perilaku memilih (voting behavior) bisa didefinisikan sebagai keputusan seorang pemilih dalam memberikan suara kepada kandidat tertentu baik dalam pemilihan anggota legislatif maupun eksekutif. Dalam ilmu politik dikenal dua macam pendekatan dalam menganalisis voting behavior: (1) Mazhab Columbia, yaitu analisis menggunakan pendekatan sosiologis. Aliran ini melihat voter dari latar belakang perseorangan atau kelompok berdasarkan jenis kelamin, kelas sosial, ras, etnik, agama, ideologi bahkan daerah asal yang bisa menentukan keputusan untuk memberikan suara pada saat pemilihan; (2) Mazhab Michigan dengan pendekatan psikologisnya. Pada mazhab ini, kualitas personal sang kandidat, performa pemerintah, isu-isu yang dikembangkan sang kandidat, dan loyalitas terhadap sebuah partai bisa mempengaruhi pilihan voter.

Beberapa penelitian menunjukkan bahwa ada perbedaan pola perilaku dalam memilih antara laki-laki dan perempuan. Perempuan cenderung lebih konservatif dalam menentukan pilihannya dibanding lakilaki (Inglehart \& Norris, 2000). Studlar, McAllister \& Hayes (1998) menemukan ada kesenjangan yang jauh antara tahun 1964 sampai tahun 1992, yaitu perempuan lebih memilih partai Demokrat 10 persen lebih 
banyak dibanding dengan laki-laki. Hasil ini menurut peneliti merupakan bentuk dari perbedaan pertimbangan dalam memilih antara laki-laki dan perempuan. Pola voting perempuan berbeda dengan laki-laki karena perempuan mempunyai pandangan yang berbeda pada isu-isu tertentu, misalnya kemiskinan, kesetaraan gender, aborsi, dan hukuman mati (Studlar, et al, 1998).

Sebelum lebih jauh membahas tentang pola perilaku memilih pada perempuan dan laki-laki, tentu ada baiknya dilihat lebih dulu perbedaan mendasar tentang gender yang meliputi kapasitas biologis, lingkungan sosial perempuan dan laki-laki tinggal, serta interaksi antara biologi dan budaya. Tiga perspektif umum tentang asal-usul pola gender didasarkan pada faktor biologis, sosialisasi, dan peran sosial.

Biologi. Perbedaan gender yang paling mendasar adalah dipengaruhi oleh faktor biologis. Secara biologis jelas ada perbedaan fisik yang mencolok, seperti dalam perkembangan otot dan tinggi badan, dalam hal kemampuan mengasuh anak dan memberi ASI, dan perempuan memiliki kemampuan untuk mengandung dan melahirkan. Sejak awal perempuan secara alamiah dianggap memilki peranan dan tugas sebagai pengatur rumah tangga. Sementara laki-laki karena memiliki otot yang lebih besar maka mereka mempunyai tugas untuk berburu dan mencari nafkah untuk keluarga (Budiman, 1985). Bem (1981) menyebut pembagian semacam ini sudah berkembang sejak berabad-abad yang lalu kerena memang pada dasarnya itu berasal dari organisasi kemasyarakatan di setiap budaya manusia.

Sosialisasi. Perspektif sosialisasi menekankan pada banyaknya cara orang mempelajari tentang gender dan mendapatkan perilaku "sesuai jenis kelamin" sejak awal masa anak-anak (Eckes \& Trautner, 2000 dalam E.Taylor, Shelley, dkk. 2009). Gagasan yang penting disini adalah masyarakat mempunyai ekspektasi dan standar yang berbeda-beda untuk perilaku laki-laki dan perempuan. Misalnya, seiring dengan pertumbuhan anak, mereka mempelajari perbedaan gender ini melalui proses penguatan dan modeling. Menurut perspektif sosialisasi, beragam pengalaman sosial yang dialami anak perempuan dan anak laki-laki itu akan menyebabkan menguatkan adanya perbedaan gender dalam sikap, minat, keahlian, dan personalitas, bahkan hingga terbawa ke masa dewasa.

Peran Sosial. Kehidupan orang dewasa ditata berdasarkan berbagai peran, seperti anggota keluarga, pekerja, dan anggota komunitas atau masyarakat. Ide utamanya adalah bahwa banyak peran sosial yang penting yang didefinisikan secara berbeda untuk perempuan dan laki-laki. Dalam keluarga misalnya, orang biasanya punya ekspektasi berbeda untuk ibu dan ayah, untuk suami dan istri, serta anak perempuan dan anak laki-laki. Dalam dunia kerja, peran okupasional sering didasarkan pada jenis kelamin. Perawat, juru ketik, dan guru TK atau SD biasanya adalah wilayah perempuan dan guru olah raga, pengobatan, konstruksi adalah wilayah laki-laki. Dalam organisasi bisnis, pekerjaan perempuan sering berada pada status rendah (Taylor, E., S., dkk., 2009).

Secara tradisi, perbedaan peran sosial mempengaruhi perilaku perempuan dan lakilaki dalam beberapa hal. Perbedaan peran ini semakin melanggengkan pembagian kerja berdasarkan gender; perempuan bekerja di rumah mengasuh anak sedangkan laki-laki bekerja untuk mencari nafkah di luar rumah. Peran juga dapat mempengaruhi keahlian dan minat seseorang yang muncul sejak masa kecil kemudian dikembangkan di masa dewasa. Efek peran berbasis gender ini mungkin pada akhirnya akan melebar ke situasi lain.

Perbedaan pembagian peran gender sejak awal dipelajari dari lingkungan 
keluarga, ajaran agama, atau dari pengalaman kerja yang menekankan bahwa laki-laki lebih memiliki status lebih tinggi dan otoritatif daripada perempuan. Ketika bertemu orang baru, seseorang akan menggunakan jenis kelaminnya sebagai petunjuk awal, misalnya dengan mengasumsikan bahwa laki-laki adalah pemimpin yang percaya diri dan perempuan adalah pengikut (Eagly, 1987 dalam Taylor, E. S.,dkk., 2009).

Menurut teori peran sosial, perbedaan perilaku perempuan dan laki-laki terjadi karena dua jenis kelamin itu menempati peran sosial yang berbeda dalam kehidupan sehariharinya. Orang biasanya menyesuaikan diri dengan norma yang diasosiasikan dengan peran spesifik dan berperilaku yang tepat secara sosial (Taylor, E. S.,dkk., 2009). Dalam konteks budaya tradisional yang patriarkis, konsepsi pembeda antara laki-laki dan perempuan sering dipandang berdasarkan fakta biologis. Dalam budaya seperti itu, perempuan dipandang memiliki status yang lebih rendah daripada laki-laki. Dalam hal ini MacKinnon (1979) mengatakan bahwa "the biological sex difference has been both exaggerranted and to justify different treatment". Karena itu, pengertian peran kemudian lebih ditekankan pada bagaimana perilaku dan sifat untuk masing jenis kelamin.

Farley (dalam Bem, 1981) menjelaskan masalah peran jenis ini sebagai suatu pembiasaan (conditioning) masyarakat terhadap anak perempuan dan laki-laki, dimana anak laki-laki diajari untuk mandiri, berinisiatif untuk mengambil tindakan, berorientasi pada tugas, rasional dan analitis sedangkan anak perempuan dididik untuk mampu bersimpati, bersifat non-kompetitif, bergantung dan penolong. Standar tersebut terus menerus dijadikan patokan dari perilaku yang normal serta tetap menjadi tuntutan masyarakat bahkan terhadap orang yang sudah dewasa sekalipun. Alhasil, peran jenis laki-laki itu mendorong mereka untuk menjadi lebih agresif, kuat, dominan, serta kompetitif dan hal ini berlaku bagi laki-laki di segala bidang. Sementara kondisi sosial seperti itu menguatkan pola pikir bahwa perempuan lebih lembut dan pasif serta penurut pada laki-laki (MacKinnon, 1979). Terdapat sebuah penelitian tentang stereotip perempuan dan laki-laki yang dilakukan oleh Broverman dan Rosenkrantz (Deaux, 1984) yang kemudian diperoleh serangkaian sifat hangat dan ekspresi sebagai sifat dari perempuan serta kompetensi dan sifat rasionalitas sebagai karakter dari laki-laki.

Berdasarkan uraian mengenai perbedaan peran jenis perempuan dan lakilaki di atas, maka dapat ditarik kesimpulan bahwa ada beberapa aspek yang dinilai sebagai pembeda peran jenis perempuan dan laki-laki, yaitu aspek perilaku dan aspek sifat. Aspek sifat dibagi ke dalam sifat feminin pada perempuan dan maskulin pada laki-laki. Perempuan memiliki sifat hangat, emosional, lemah lembut dan pasif sebagai sifat feminin. Sedangkan laki-laki memiliki sifat rasional, kompetitif, dominan, tidak bergantung dan penuh percaya diri sebagai sifat maskulin.

Terkait dengan nilai dan perilaku memilih perempuan dan laki-laki, menarik untuk dilihat pertimbangan voter dalam sebuah pemilihan seorang pemimpin. Oleh karena itu, penelitian ini berusaha menelusuri alasan seseorang untuk menentukan pilihannya pada pemilihan umum kepala daerah (PEMILUKADA) dengan menggunakan simulasi, terutama yang terkait dengan gender.

\section{METODE}

Penelitian melibatkan 90 responden yang terdiri dari 30 mahasiwa Perguruan Tinggi Agama Islam Negeri (PTAIN) Malang (15 laki-laki dan 15 perempuan), 30 mahasiswa dari sebuah Perguruan Tinggi 
Negeri (PTN) di Malang (15 laki-laki dan 15 perempuan), dan 30 mahasiswa Politeknik (Poltek) di Malang (15 laki-laki dan 15 perempuan).

Untuk memperoleh data yang diperlukan, peneliti menggunakan simulator skenario yang berisi kasus tentang pemilihan calon gubernur yang memiliki jenis kelamin berbeda tapi memiliki visi dan misi kepemimpinan yang sama kuatnya. Dari kasus ini, responden yang diilustrasikan sebagai pemilih diberikan tiga jawaban alternatif, yaitu memilih calon gubernur perempuan, memilih calon gubernur laki-laki atau tidak memilih sama sekali. Simulasi ini terdiri dari dua bagian, pertama mengungkapkan identitas subjek dan yang kedua berisi tentang kasus. Setiap jawaban yang dipilih oleh subjek harus disertai dengan alasannya, sehingga dari alasan tersebut dapat diketahui bagaimana pola pikir subjek tentang fenomena yang sedang diteliti. Data yang terkumpul dianalisis menggunakan teknik analisis tematik kualitatif.

\section{HASIL DAN PEMBAHASAN}

Berdasarkan angket dan skenario yang diberikan pada subjek penelitian ditemukan hasil yang bervariasi pada masing-masing kelompok seperti yang tertera dalam tabel di bawah ini.

Dari hasil penelitian di bawah dapat diketahui secara umum bahwa pemimpin lakilaki masih menjadi pilihan terbanyak responden. Responden yang memilih laki-laki sebagai pemimpin sebanyak 68 orang $(75,56 \%)$, responden yang memilih perempuan sebagai pemimpin sebanyak 12 orang $(13,33 \%)$, dan responden yang abstain sebanyak 10 orang $(11,11 \%)$.

Hasil penelitian angket di atas juga dapat diketahui bahwa perilaku memilih pada perempuan relatif sama dengan laki-laki. Indikasinya adalah meskipun mereka memilki peran jenis yang berbeda tetapi pemahaman mereka terhadap konsep peran jenis antara laki-laki dan perempuan adalah sama. Hasil penelitian juga menunjukkan bahwa perilaku perempuan dalam memilih cenderung lebih memilih laki-laki sebagai pemimpin. Hal ini bisa terjadi karena perempuan yakin dan percaya bahwa yang lebih berhak dan pantas menjadi pemimpin adalah laki-laki. Setidaknya itu terlihat dari alasan-alasan yang dikemukakan oleh beberapa responden, seperti karena adanya dalil dalam Islam yang menyatakan "arrijalu Qawwamuna 'Alannisa" (laki-laki adalah pemimpin kaum perempuan). Bagi sebagian responden, makna dari kalimat tersebut merupakan petunjuk bagi ummat muslim bahwa laki-laki itu "lebih" daripada perempuan, sehingga lakilaki lebih pantas menjadi pemimpin. Selain itu, mereka juga berpegang pada alasan lainnya, seperti semua nabi adalah laki-laki dan mereka bisa dengan baik memimpin ummat-ummatnya. Alasan-alasan tersebut muncul dari para mahasiswa dan mahasiswi dari PTAIN.

Tabel 1. Distribusi Responden Pemilihan

\begin{tabular}{|c|c|c|c|c|c|}
\hline No & $\begin{array}{c}\text { Perguruan } \\
\text { Tinggi }\end{array}$ & $\begin{array}{c}\text { Jenis } \\
\text { kelamin }\end{array}$ & $\begin{array}{c}\text { Memilih } \\
\text { Perempuan }\end{array}$ & $\begin{array}{l}\text { Memilih } \\
\text { Laki-laki }\end{array}$ & $\begin{array}{c}\text { Tidak } \\
\text { Memilih }\end{array}$ \\
\hline \multirow{2}{*}{1} & \multirow{2}{*}{ PTAIN } & Perempuan & 2 orang & 11 orang & 2 orang \\
\hline & & Laki-laki & 1 orang & 13 orang & 1 orang \\
\hline \multirow{2}{*}{2} & \multirow{2}{*}{ PTN } & Perempuan & 8 orang & 5 orang & 2 orang \\
\hline & & Laki-laki & - & 13 orang & 2 orang \\
\hline \multirow{2}{*}{3} & \multirow{2}{*}{ Politeknik } & Perempuan & 1 orang & 14 orang & - \\
\hline & & Laki-laki & - & 12 orang & 3 orang \\
\hline \multicolumn{3}{|c|}{ Jumlah } & 12 orang & 68 orang & 10 orang \\
\hline \multicolumn{3}{|c|}{ Total } & & 90 orang & \\
\hline
\end{tabular}


Selain beberapa alasan di atas, alasan yang berkaitan dengan kemampuan atau kompetensi juga dikemukakan oleh sebagian responden:

Dari segi fisik dan psikis, pria lebih pantas dalam memimpin. Contohnya, pria lebih terkontrol emosinya, sedangkan wanita memiliki masa-masa yang sulit untuk mengontrol emosi atau aspek perilaku (misalnya pada masa menstruasi).

Ada pula alasan responden yang cukup menarik dari sebuah PTN, sebagian besar responden mahasiswi yang berasal dari jurusan hukum cenderung lebih memilih perempuan sebagai pemimpin. Alasannya, perempuan juga memilki kemampuan tidak kalah baik dari laki-laki. Mereka juga menambahkan bahwa perempuan lebih bisa menempatkan diri jika terpilih dan lebih peka terhadap rakyat karena perempuan mengandalakan perasaan. Alasan lain yang mungkin paling utama bagi mereka adalah adanya keinginan untuk mencapai kesetaraan gender, hal itu tercermin dari ungkapan "agar wanita tidak terus berada di bawah kedudukan laki-laki”. Meski begitu, beberapa di antara kelompok mahasiswa PTN juga masih memilih laki-laki sebagai pemimpin dengan alasan laki-laki memiliki kompetensi yang lebih baik daripada perempuan.

Sementara itu, ada perbedaan pilihan yang sangat mencolok di kalangan responden mahasiswa dari Poltek. Dari 30 mahasiswa (15 laki-laki dan 15 perempuan) hanya ada satu orang perempuan yang memilih perempuan sebagai pemimpin, sisanya lebih memilih laki-laki sebagai pemimpin. Kebanyakan dari mereka beralasan bahwa laki-laki lebih mempunyai kemampuan kognitif yang lebih baik dari perempuan, misalnya salah satu responden mengatakan:

Pria lebih terlihat berwibawa daripada perempuan, laki-laki juga cenderung lebih tegas dan menggunakan logika.
Sementara yang lain beralasan memilih laki-laki karena melihat perempuan kurang mampu mengendalikan emosinya. Seorang responden perempuan menyatakan:

Sebagai pemimpin diperlukan ketegasan dan kontrol emosi. Terdapat fakta bahwa wanita memiliki sisi negatif, yakni kontrol emosi yang kurang stabil (mudah terpengaruh situasi). Dari situ dapat disimpulkan kekurangakurasian keputusan yang diambil.

Alasan yang dikemukakan di atas menunjukkan bahwa responden penelitian ini tampaknya memperteguh beberapa hasil penelitian bahwa perempuan lebih konservatif dibanding dengan laki-laki dalam penentuan pilihannya (Inglehart \& Norris, 2000). Namun, kecenderungan ini tidak terjadi pada semua perempuan mahasiswa PTN yang menjadi responden.

Nilai peran gender yang berkembang di masyarakat dan "diamini" sampai dewasa ini menjadi faktor penting yang bisa memengaruhi pilihan responden. Bilksy \& Schwartz (1996) mengatakan bahwa nilai yang dipegang seseorang akan tercermin dari pilihan-pilihan dalam bersosialisasi. Feather (1994) menambahkan bahwa nilai berhubungan dengan keadilan yang dirasakan oleh seseorang. Seperti yang dikemukakan di atas bahwa nilai-nilai peran gender patriarki telah memengaruhi pandangan individu bahwa laki-laki labih superior dibanding perempuan, terutama untuk urusan publik. Hal ini terlihat bahwa mahasiswa PTAIN lebih mengedepankan nilai-nilai agama dibandingan dengan kelompok responden yang lain.

Nilai-nilai ini tampaknya terinternalisasi secara tanpa sadar pada diri para responden yang hidup dalam struktur sosial masyarakatnya. Dalam penelitiannya, Ulfaizah (2006) menyimpulkan bahwa interaksi sosial masyarakat berpengaruh terhadap partisipasi politik masyarakat. 
Pengaruh itu berasal dari interaksi yang terjadi dalam keluarga, tempat kerja, dan organisasiorganisasi kemasyarakatan dengan tokoh agama berperan sebagai tokoh politik. Hal semacam itulah yang berpengaruh terhadap pilihan politik responden penelitian ini yang lebih cenderung memilih laki-laki. Perbedaan antara laki-laki dan perempuan juga dilatarbelakangi oleh pembentukan kesan yang dibangun oleh media massa (Karakowsky \& Siegel, 1999). Intensitas dan manejemen kesan yang tampak pada iklan politik terutama di media massa merupakan faktor eksternal yang tampaknya memiliki pengaruh cukup dominan terhadap perilaku memilih (voting behaviour) responden penelitian ini.

\section{SIMPULAN}

Hasil penelitian ini menunjukkan bahwa tidak ada perbedaan kecenderungan perilaku pemilih antara pemilih laki-laki dan perempuan yang menjadi responden penelitian ini dalam konteks pemilihan pemimpin daerah. Alasan-alasan pemilihan sangat dipengaruhi oleh nilai-nilai yang dipegang dalam masyarakat. Dominannya budaya tradisional yang patriarkis mengakibatkan lebih disukainya calon pemimpin laki-laki daripada perempuan khususnya dalam konteks sosial di mana para responden penelitian ini berasal. Latar belakang pendidikan para responden (mahasiswa) juga tidak banyak memengaruhi nilai-nilai peran jender patriarkis yang telah terinternalisasi dalam diri mereka.

Implikasi dari penelitian ini adalah pemahaman tentang perilaku memilih dan faktor psikologis yang mendasarinya sangat diperlukan untuk memahami perilaku politik. Memang ada ke-khas-an tersendiri dalam perilaku berpolitik di Indonesia terkait dengan gender. Nilai Indonesia terkait dengan peran gender juga berbeda. Budaya patriarki juga dominan pada peran gender yang dianut pada masyarakat. Meskipun demikian, secara ilmiah penelitian ini masih bisa dikembangkan dengan melihat perbedaan sosial budaya, misalnya daerah perkotaan dan pedesaan. Perilaku politik, khususnya penentuan pilihan mahasiwa, seperti dalam penelitian ini, tentu berbeda dengan perilaku politik orang pedesaan yang lebih tergantung pada patron yang mereka anut.

\section{DAFTAR PUSTAKA}

Arifin, N. (2008). Kemenangan Perempuan dalam Pemilihan Kepala Daerah Langsung. http://klikpolitik.blogspot. com/2008/03/kemenangan-perempuandalam-pemilihan.html. Diakses, 5/06/2010

Bilksy, W. \& Schwartz, S. H. (1996). Values and Personality. European Journal of Personality. 8, 163-181.

Bem, S. L. (1981). Gender Scema Theory: A Cognitif Acount of sex Typing. Psychologycal Review. 88. 354-364.

Budiman, A. (1985). Pembagian Kerja Secara Seksual: Sebuah Pembahasan Sosiologis Tentang Peran Wanita Di Dalam
Masyarakat. Jakarta: Gramedia.

Deaux, K. (1984). From Individual Differences To Social Categories Analysis of Te Decade Research On Gender. American Psychology.

Taylor, E. S., dkk. (2009). Psikologi Sosial. Jakarta: Kencana Prenada.

Feather, N. T. (1994). Human Values and Their Relation to Justice. Journal of Social Issues, 50. 129-151.

Inglehart, R \& Norris. R. (2000). The Developmental Theory of the Gender Gap: Women's and Men's Voting Behavior in Global Perspective International Political 
Science Review 21.441-463.

Karakowsky, L. \& Siegel, J.P. (1999). The effects of proportional representation and gender orientation of the task on emergent leadership behavior in mixed-gender work groups. Journal of Applied Psychology, 84, 620-631.

MacKinnon, C.A. (1979). Sexual Harrasment of Working Women. London: Yale University Press.
Studlar, D. T., McAllister, I. \& Hayes, B. C. (1998). Explaining the gender gap in voting: A crossnational analysis. Social Science Quarterly, 79, 779-798.

Squires, J. (1999). Gender in Political Theory. Cambridge: Polity Press.

Ulfaizah. (2006). Pengaruh Interaksi Sosial Terhadap Partisipasi Politik Masyarakat Desa Tengguli Kecamatan Bangsri Kabupaten Jepara. Semarang: FIS Unnes. 